\title{
Reference Desk Consultation Assignment
} An Exploratory Study of Students'
Perceptions of Reference Service

This paper describes the experience of three sophomore English composition classes that were required to visit the reference desk for class credit. Student perceptions of reference consultations are analyzed to gain a clearer understanding of the students' attitudes toward reference services. Findings of this exploratory study indicate that students suffer from library anxiety and are much more likely to seek out reference help if they are convinced that a consultation will save them time.

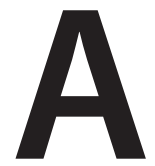
$\mathrm{s}$ an English composition instructor and an information literacy librarian who collaborate to teach sophomore classes, we want our students to take full advantage of the library's reference services. However, it has become painfully evident to us that including the following "tip" on college composition assignment descriptions will not result in student action: "Our class librarian is available for help in locating sources for your research paper." Though students will nod in fascination as the course instructor delivers her spiel about librarian expertise-explaining such baffling concepts as "Boolean," "peer-reviewed," and "discourse community" — we have come to realize that neither discussing nor writing about this largely untapped resource actually spurs student initiative. Nunberg's observation that "most people will fall back on perfunctory techniques for finding and evaluating information online" is validated in our experience every semester. ${ }^{1}$ We have concluded that where there is no will to consult a librarian, there is no way it will happen.

Recent research corroborates our experience in the classroom and library. During a library study on subject searching in the library catalog, students who had conducted unsuccessful searches were asked what they would do next to locate the information they needed. ${ }^{2}$ Though they were searching the library catalog in a library, not one student mentioned asking a librarian. This is just another example of a larger trend. Librarians are being asked less and less for help. According to the Association of Research Libraries (ARL), reference transactions have dropped 51 percent since $1991 .{ }^{3}$ In recent years there have been many debates about the nature and utility of the reference desk, largely in response to declining reference statistics. Libraries have attempted to combat this decrease in demand by offering reference services in new ways. Librarians have experimented with new forms and technologies to conduct reference consultations. Some reference desks have entirely disappeared; some

\section{Pamela N. Martin and \\ Lezlie Park}

Pamela N. Martin is Reference Librarian, Merrill-Cazier Library, and Lezlie Park is Lecturer, Department of English, Utah State University, Logan. Submitted for review April 20, 2009; revised and accepted for publication June 22, 2009.

Reference \& User Services Quarterly, vol. 49, no. 4, pp. 333-340

(c) 2010 American Library Association. All rights reserved.

Permission granted to reproduce for nonprofit, educational use. 
have merged with other library service points. While reference librarians have many different views about what a reference consultation should or could be and what role the reference desk should play, our study focuses on students' attitudes. In light of falling reference desk transactions, do students perceive one-on-one consultations with a reference librarian as useful?

To answer this question, we conducted an exploratory qualitative study at Utah State University (USU). USU is a land-grant university with roughly fourteen thousand students enrolled full-time. For our study, USU students in three sophomore English composition classes received classroom library instruction and were then required to visit the reference desk on their own. After completing the reference consultation, they filled out an informal anonymous survey about their experience. All participating students were from classes taught by the same instructor and librarian. In addition to informing the debate and experimentation surrounding the reference desk, and describing the reference desk consultation assignment, our study's primary objective is to assess student perceptions of reference interview transactions. A clearer understanding of students' attitudes toward reference services is a necessary step toward theorizing strategies for reversing the downward trend.

\section{LITERATURE REVIEW}

Many published studies have focused on students' perceptions of reference services. In her 1998 article, Massey-Burzio describes focus groups that were conducted at Johns Hopkins University to gain student and faculty insight into reference services. ${ }^{4}$ Thirty-eight students and faculty members were interviewed, and Massey-Burzio found that patrons were not comfortable asking for help, often found service points unhelpful, and had an overblown sense of their own library skills. She also reported a "lack of interest in [library instruction] classes." She recommended that professional librarians be clearly recognizable and better marketed to the campus community. In addition, Massey-Burzio suggested that the "teaching/learning library philosophy as practiced in formal classes" be dropped. ${ }^{6}$ At Central Missouri State University, 201 undergraduates were surveyed concerning their perceptions of reference, and Sandra Jenkins concluded that "students do not have a clear perception of the reference collection or the reference librarian." While these studies paint a bleak picture of student perceptions of reference services, other studies indicate that students with more library experience (especially in the classroom) appreciate and understand reference services to a greater degree.

Saunders, analyzing ARL data, found that library instruction actually "increases the demand for reference services." In a recent study, Gremmels and Lehmann investigated college students and librarians' perceptions of learning in reference consultations. ${ }^{9}$ They found that students not only saw reference work as instructional but also "understood the connection between reference instruction and their in-class [library] instruction."10 So perhaps the problem is not too much library instruction, as Massey-Burzio postulated, but not enough. Indeed, Fister discussed students' "fear" in a 2002 Chronicle of Higher Education column and called on librarians and professors to collaborate to create more meaningful reference experiences for students. ${ }^{11}$

\section{REFERENCE DESK CONSULTATION ASSIGNMENT}

Similar to Fister's suggestion, in our classes we found that convincing students to value reference librarians' skills can be accomplished most effectively by incorporating a reference consultation into a larger writing assignment (read with points attached). On their own, students often overestimate their ability to locate credible information. Nunberg makes this point using results from a Pew Project survey in his article "Teaching Students to Swim in the Online Sea":

There is a paradox in the way people think of the Web. Everyone is aware that it teems with rotten information, but most people feel confident that they can sort out the dross ... 87\% of search-engine users said they found what they were looking for all or most of the time... [yet] only 38 percent of search-engine users were aware of the difference between unpaid and sponsored search results, and only 18 percent could tell which was which. ${ }^{12}$

The end result of this naiveté in composition classes includes embarrassing reference lists (e.g., ".biz" websites, National Enquirer articles, or the grandmother of them all, Wikipedia entries) or worse: sources that only remotely relate to the research topic.

When hearing that librarian consultations are a required part of the research project, students utter a collective sigh; however, they often comment afterwards that they experienced a "breakthrough" 
in their information search during the consultation with a librarian, as is evidenced in the following remark from one of our post-assignment surveys:

I didn't think they [the librarians] could really help but they looked in resources I didn't know about or consider but yeilded [sic] results.... She [the librarian] was very approachable and helped me find several odd resources relevant that I wouldn't have found otherwise.

The reference desk consultation assignment hopefully not only leads to better student research performance but also provides an experienced group of library users to study. These students have had many interactions with librarians, and our exploratory study focuses on these transactions.

At USU, the Merrill-Cazier Library emphasizes library instruction; consequently, all reference librarians carry heavy teaching loads. Library instruction sessions are course-integrated, and general-education English composition classes in particular participate in multiple library instruction sessions per class. Sessions include traditional librarian-led classes as well as workshop time. During the series of instruction sessions for any given class, librarians will usually demonstrate searching and spur class discussion; but students are also given hands-on research time and can consult one-on-one with the librarian.

In spring 2008, three sophomore English composition classes visited the Merrill-Cazier Library for a series of four library instruction sessions, led by a librarian. In addition to those sessions, we attached a reference desk assignment to their persuasive research paper. This assignment was designed to encourage student-librarian interaction and to help students understand where to ask for reference help in the future. Students were required to attend a fifteen-minute reference desk consultation with a detailed research proposal in hand. We instructed them to steer the consultation and be headed in a specific research direction. At the consultation, students gave the librarian working at the desk their names, and librarians recorded the names in a file kept at the desk for the class records. Students could approach any librarian at the reference desk, and all reference desk librarians were informed of the assignment ahead of time and given instructions for recording the transactions. The reference desk assignment was worth 20 points and was factored into students' final persuasive research paper score. Since the paper was worth 150 points total, the maximum score a student could earn on this last and most heavily weighted assignment without completing the reference desk consultation assignment was 130 out of 150 , or 86 percent, a B.

\section{METHOD}

At the end of the semester, after the assignment due date was past, an informal, anonymous survey was distributed to the students. The survey consisted of open-ended questions:

1. What time does your class meet?

2. What was the most useful thing about consulting with a librarian?

3. How would you rate the approachability and helpfulness of the librarian you worked with?

4. What was the biggest challenge in doing your research?

5. Would you consult a librarian again for another research assignment? Why or why not?

6 . If you did not do a consultation, what was the reason you chose not to?

Among the three classes, 76 of 85 students (89 percent) completed the survey.

After collecting and closely reading students' responses, we coded each student's survey with tags signifying themes the student mentioned. This coding technique is described by Gorman and Clayton as "the key to meaningful data analysis" and allows us to create "new descriptive configurations" from the responses to the open-ended survey questions..$^{13}$ In effect, coding the responses allows us to look for common themes and associations in the survey results.

To create tags with which to code the responses, we looked for common words, phrases, and meanings in the students' open-ended responses. For instance, many respondents valued librarians who offered a new perspective in their research process, so we created the tag different insight/perspective. A few of the responses that were coded with this tag used phrases like "second opinion," "different ideas," "different views," and "getting more ideas," when answering question 4 , "What was the most useful thing about consulting with a librarian?" Relevancy was coded to a response not only when the word "relevant" was present but also when the student described, for example, "finding applicable resources" or "finding the right information." We coded each survey response with all appropriate tags, which means most responses received multiple tags. More examples of tags and their corresponding survey responses are included in table 1. 
Table 1. Tags

\begin{tabular}{|c|c|c|c|}
\hline Tag & $\begin{array}{l}\text { Number of } \\
\text { Responses }\end{array}$ & $\begin{array}{l}\text { Percentage } \\
\text { of Total } \\
\text { Responses }\end{array}$ & $\begin{array}{l}\text { Quotes from Corresponding Survey } \\
\text { Responses (Question \# to which the } \\
\text { Quote is Responding) }\end{array}$ \\
\hline Locating sources & 35 & $46 \%$ & "Finding the actual sources." (\#4) \\
\hline Relevancy & 32 & $42 \%$ & $\begin{array}{l}\text { "Getting the specific research that I needed } \\
\text { that dealt directly with my topic." (\#4) }\end{array}$ \\
\hline Professional knowledge & 27 & $36 \%$ & $\begin{array}{l}\text { "The librarian's extensive knowledge of com- } \\
\text { puter data bases and how to use them." (\#2) }\end{array}$ \\
\hline Time & 25 & $33 \%$ & $\begin{array}{l}\text { "It helped me know faster ways to find what } \\
\text { I'm looking for." (\#2) }\end{array}$ \\
\hline Topic & 24 & $31 \%$ & $\begin{array}{l}\text { "The biggest challenge is narrowing my re- } \\
\text { search and finding specific sources." (\#4) }\end{array}$ \\
\hline Different insight & 13 & $17 \%$ & $\begin{array}{l}\text { "They [the librarians] helped me see different } \\
\text { ways of finding sources." (\#2) }\end{array}$ \\
\hline Narrow search & 11 & $14 \%$ & $\begin{array}{l}\text { "Help with narrowing down my search fields." } \\
(\# 2)\end{array}$ \\
\hline Information overload & 10 & $13 \%$ & $\begin{array}{l}\text { "The biggest challenge in doing my research } \\
\text { was narrowing down my topic and searching } \\
\text { through the massive amounts of information } \\
\text { to find exactly what I needed." (\#4) }\end{array}$ \\
\hline Library anxiety & 10 & $13 \%$ & $\begin{array}{l}\text { "I felt I had dumb questions, but she didn't } \\
\text { treat them like they were stupid, so that was } \\
\text { helpful." (\#3) }\end{array}$ \\
\hline Keywords & 10 & $13 \%$ & $\begin{array}{l}\text { "Learning what key words were the most } \\
\text { helpful." (\#2) }\end{array}$ \\
\hline Critical thinking & 9 & $12 \%$ & $\begin{array}{l}\text { "It gave me a good starting point for con- } \\
\text { tinuing to develop my thesis and follow up } \\
\text { research." (\#2) }\end{array}$ \\
\hline Databases & 8 & $10 \%$ & $\begin{array}{l}\text { "Finding all the different research databases } \\
\text { from the library homepage to use for scholarly } \\
\text { sources." (\#2) }\end{array}$ \\
\hline On my own & 7 & $9 \%$ & $\begin{array}{l}\text { "No. I can usually do things by myself and } \\
\text { find my own resources." (\#5 \& 5A) }\end{array}$ \\
\hline Website & 7 & $9 \%$ & $\begin{array}{l}\text { "Learning more about the library website for } \\
\text { research." (\#2) }\end{array}$ \\
\hline $\begin{array}{l}\text { Scholarly/peer-reviewed } \\
\text { sources }\end{array}$ & 6 & $8 \%$ & "Learning how to find scholarly articles." (\#2) \\
\hline Start & 5 & $7 \%$ & $\begin{array}{l}\text { "Yes. Because it was helpful to know where to } \\
\text { START!" (\#5 \& 5A) }\end{array}$ \\
\hline Credibility of sources & 5 & $7 \%$ & $\begin{array}{l}\text { "Yes. It saved me the hassel [sic] of trying to } \\
\text { figure out where to get reliable information." } \\
(\# 5 \& 5 \mathrm{~A})\end{array}$ \\
\hline Library instruction & 3 & $4 \%$ & $\begin{array}{l}\text { "I never met with a librarian but I was helped } \\
\text { in my class." (\#2) }\end{array}$ \\
\hline Motivation & 3 & $4 \%$ & "Being motivated to do it." (\#4) \\
\hline
\end{tabular}


Specific tags were not found to be exclusive to certain survey questions. That is, while more of the relevancy themes were found in response to question 4, this theme was also found in response to questions 2,3 , and 5 . Indeed, many of the relevancy respondents reported relevancy themes in more than one question response. Because almost all the tag themes could be found in response to almost all of the open-ended questions, our analysis focuses on the tags. We did not break down and analyze responses and tags by question because of this variation and because the tagging process had already effectively revealed themes in the responses.

\section{DISCUSSON}

Even though visiting the reference desk was a required course activity, not all students chose to participate. According to class records, only 56 of 85 students (66 percent) completed this assignment. This number is lower than the students' selfreported reference desk activity. According to the anonymous surveys, 65 of 76 (86 percent) student respondents completed the assignment (see table 2). There a few likely reasons for this discrepancy other than deliberate misinformation. Librarians may have forgotten to record students' reference desk visits, or the students may not have indicated that they were completing a class assignment at the time of the consultation and therefore did not get credit in the class records. Some students also may not have fully understood the assignment and thought consulting with a librarian in the library instruction sessions completed the requirement. Because of this discrepancy, we cannot be sure all student comments refer only to the reference desk. Some students may just be reflecting on in-class consultations with the librarian. However, their comments are helpful in understanding the larger student perspective of consultations with reference librarians.

The survey responses indicated that students who did not participate in a reference consultation felt they could research on their own, had no time, forgot about the assignment, or did not give the consultation assignment high priority. The following is a sample of student responses:

[I had] more important classes that needed my attention.

The help I received to search on the net during our workshops was enough to help me find what I needed (and, yes, those are scholarly sources).

A large portion, sixty-six students (87 percent), reported that they would consult again with a librarian while six students ( 8 percent) stated they would not. Four respondents (5 percent) did not answer this question. Of the six who said they would not seek reference librarian help again, four of them said they would not do so because they felt confident in their ability to locate information on their own in the future. Three implied that they learned how to research well enough from library instruction sessions or from the reference desk interactions to believe they would be able to research without reference help in the future. While the response to question 5 seems overwhelmingly positive toward reference desk consultations, other issues brought out in the survey, which we discuss below, seem to gray this area.

Table 1 indicates how many responses were coded with each tag. The tagging process revealed nearly twenty common themes in respondents' remarks. Comments indicate that most students found librarians' professional knowledge helpful and that they appreciated learning how to locate sources and find relevant information. In fact, locating sources, professional knowledge, and relevancy were the three most frequent tags (see table 1). The popularity of these tags and many of the others is not unexpected. Librarians make use of professional knowledge to locate relevant sources for students and help them learn search skills. While the high frequency of these tags reveals positive conceptions of reference interactions and substantiate reference and instruction objectives, many slightly less common tags revealed more complex and occasionally less positive conceptions.

Table 2. Completion Rates for Reference Desk Consultation

\begin{tabular}{lcc}
\hline & Class Records & Survey Self Reporting \\
Completed Reference Desk Consultation & $56(66 \%)$ & $65(86 \%)$ \\
Failed to Complete Reference Desk Consultation & $29(33 \%)$ & $11(14 \%)$ \\
Total & $\mathbf{8 5 ( \mathbf { 1 0 0 } \% )}$ & $\begin{array}{c}\mathbf{7 6}(\mathbf{1 0 0 \%} \text { of surveys; } \mathbf{8 9} \% \text { of } \\
\text { class enrollment) }\end{array}$ \\
\hline
\end{tabular}




\section{Associated Tags}

Twelve percent of respondents discussed critical thinking; this indicates that some students were encouraged to think beyond merely finding the required number of resources for their persuasive papers. Additionally, many respondents who mentioned critical thinking also discussed topics. One logical explanation for this link might be that discussion of their paper topics in library instruction sessions led students to think more critically about the research process. The process of explaining a research question to a reference librarian results in a conversation that illustrates the importance of specifying and refining search criteria to yield relevant results. This process can be an invaluable lesson in critical thought and precision. One student verbalized this in a response to question 4, "What was the biggest challenge in doing your research?"

Trying to put in the exact words and reaching a conclusion on a lot of my research topics. I was always trying to look for a huge broad topic, but narrowing it down helped out a lot.

The beauty of this type of transaction is that it is often self-perpetuating: Students are introduced to a skill they may not have known even existed, and they become capable of practicing that skill in future research-based projects.

A similar association seems to exist between the tags keywords and different insight. This might imply that students who appreciated the contributions of librarians' insights were also particularly impressed with librarians' skill at brainstorming different keywords or even the concept of keyword brainstorming. This may also indicate that thinking about keywords helped students to realize and appreciate that others' points of view can be helpful in the research process.

\section{Library Anxiety: A Persistent Issue}

Several comments (13 percent) were tagged with library anxiety, indicating that these students felt overwhelmed by the library and hesitant to ask for help. Library anxiety was first explicitly identified by Mellon in 1986. ${ }^{14}$ In our survey, students appear to still suffer from this affliction. They worried that their questions were "dumb" or "stupid," and they "felt a little weird asking [them]." They described the library as "huge" and mysterious and the research process as "intimidating." However, all library anxiety responses also indicated that working with librarians helped them overcome this anxiety. Eighty percent of library anxiety responses credited librarian's professional knowledge with making them feel more comfortable. These results signify the importance of personal interaction in reducing library anxiety and also further support Mellon's findings. ${ }^{15}$ Similarly, in his article "Are Reference Desks Dying Out?" Carlson also notes that the majority of students prefer face-to-face interaction. ${ }^{16}$ Despite this preference, our exploratory study revealed that many students still feel initially uncomfortable when approaching a librarian for help. Even though all library anxiety respondents said they would consult with a librarian again, we cannot know whether these students would have been able to get past their anxiety without library instruction. Would they ever approach the reference desk if it was not a class assignment or if their anxiety had not already been reduced in library instruction sessions? To overcome this anxiety-induced hesitancy, Fister claims that "being required to use the reference desk absolves the student of that strange burden of shame" so many students feel when asking for help. ${ }^{17}$ Our study seems to confirm this statement. Hopefully our reference desk consultation assignment will encourage students to establish a behavior pattern of seeking reference help that will continue through their college careers.

\section{Perceptions of Time and Reference Services}

A large portion of respondents mentioned time (33 percent). Of the twenty-five comments tagged time, there were many variations that can be broken into three sub-tags: saved time, no time, and contradictory. Most of these students (fourteen, or 56 percent of the time comments) say that consulting with a librarian saves time, and all of the saved time students say they would consult with a librarian again. When asked why they would consult with a librarian in the future, saved time respondents wrote the following:

Because i [sic] lose a lot of time researching for the wrong thing.

It would save me loads of time.

It saved me the hassel [sic] of trying to figure out where to get reliable information.

However, no time respondents (nine, or 36 percent of the time comments) expressed a concern that reference desk consultations take too much time, though seven of these students say 
they would consult with a librarian in the future. They reason that if they had time, a consultation would be helpful. Many (five out of nine) no time respondents said they did not complete the reference desk consultation assignment because of time constraints. One of the no time respondents who did complete the assignment reported that the desk consultation "took time and [it] was somewhat difficult to explain the topic and what you wanted to find in a short amount of time." Two students give contradictory statements. These students state that consulting with a librarian saves time, but they had no time to do so. One student says that working with a librarian in class "helped me to find sources quicker" but "I didn't have time to do a consultation [at the reference desk]."

Conceptions of libraries and time have been around for decades. Ranganathan's "Fourth Law of Library Science" is to "save the time of the reader."18 Ranganathan thought reference librarians, with their vast knowledge of library workings and their ability to connect a reader to resources and research tools, were fundamental to the Fourth Law. Massey-Burzio's 1998 focus group study seems to confirm that users' time is of the upmost importance. ${ }^{19}$ However, while MasseyBurzio concludes that library instruction is often a waste of time and that reference services should be better marketed to the campus community, we believe not only that library instruction classes are useful but also that these sessions offer great opportunities to market the skills of reference librarians to students. Seventy-nine percent of saved time respondents mentioned the timesaver aspect of reference consultations as the reason they would consult again. As simple as it may seem to librarians, library instructors should make explicit in class that consultations with reference librarians will save them time. Emphasizing time savings is a simpler message than extemporizing about the vastness and utility of librarians' expertise and can be conveyed in class through a quick discussion, searching demonstrations, and stump-the-librarian challenges. We feel that explicitly highlighting the time-saving benefits of reference consultations both in class and in library marketing campaigns may help convince students to engage in reference consultations.

\section{CONCLUSION}

While most of the informal survey results are highly positive, many larger questions were uncovered in the responses. Even with prior library instruction—or perhaps because of it—students in our exploratory study generally perceive value in reference desk consultations, and these consultations seem particularly helpful in decreasing library anxiety. Most students insist that they would consult with a librarian in the future. However, many students, even when they were required to do so, did not visit the desk. The survey results indicate that 14 percent of the students did not participate in the reference desk assignment while the class records set the nonparticipatory rate at 33 percent. This means that $14-33$ percent of students in our classes did not visit the reference desk. One reason for this may be that students have contradictory conceptions of time and the reference desk.

Though many students seemed to think the reference desk consultations saved them time, others claimed that they had no time for the consultations. The latter group stated that they were too busy and stressed to bother with a reference desk visit. Perhaps reference librarians are correct to experiment with service points and new ways of reaching out to students. However, the results of this exploratory study do not speak to how the reference desk should be configured or reimagined; rather, the results indicate that reference consultations should be marketed to students as time savers. What if the root cause of students' resistance to visit the reference desk is not a matter of local or technological convenience, but a misconception that librarians do not save students time? We posit that it is likely a mixture of both. Many of the students who came to the desk and who will come back in the future realize consultations with reference librarians save time. In addition, a common reason cited by students who did not visit the reference desk was a lack of time. If we can convince students that consultations actually save them time, perhaps we can begin to reverse falling reference desk statistics. However, student conceptions of time in relation to the reference desk should be examined in a more in-depth study to better understand our exploratory survey results.

In the meantime, we will continue to require our students to visit the reference desk. This assignment helps calm library anxiety and makes many students realize that reference librarians can save them time in the research and writing process. In our experience, this assignment not only convinces most students of the value of reference consultations but also produces higher quality student research, and consequently, better writing.

\section{ACKNOWLEDGEMENT}

The authors would like to thank Judy Johnson for her assistance in collecting the data used in this article. 


\section{FEATURE}

\section{References and Notes}

1. Geoffrey Nunberg, "Teaching Students to Swim in the Online Sea," New York Times, Feb. 13, 2005, www .nytimes.com/2005/02/13/weekinreview/13numb html (accessed Apr. 20, 2009).

2. Karen Antell and Jie Huang, "Subject Searching Success: Transaction Logs, Patron Perceptions, and Implications for Library Instruction," Reference \& User Services Quarterly 48, no. 1 (2008): 68-76.

3. Martha Kyrillidou and Les Bland, "ARL Statistics: 2006-2007," www.arl.org/bm doc/arlstat07.pdf (accessed Apr. 20, 2009).

4. Virginia Massey-Burzio, "From the Other Side of the Reference Desk: a Focus Group Study," Journal of Academic Librarianship 24, no. 3 (1998): 208-15.

5. Ibid., 212.

6. Ibid., 214

7. Sandra Jenkins, "Undergraduate Perceptions of the Reference Collection and the Reference Librarian in the Academic Library," The Reference Librarian 35 (2001): 239.

8. E. Stewart Saunders, "The Effect of Bibliographic Instruction on the Demand for Reference Services," portal: Libraries and the Academy 3, no. 1 (2003): 38.

9. Gillian S. Gremmels and Karen Shostrom Lehmann, "Assessment of Student Learning from Reference
Service," College \& Research Libraries 68, no. 6 (2007): 488-501.

10. Ibid., 495 .

11. Barbara Fister, "Fear of Reference," Chronicle of Higher Education, June 14, 2002, http://chronicle.com/ weekly/v48/i40/40b02001.htm (accessed May 28, 2009).

12. Nunberg, "Teaching Students to Swim in the Online Sea."

13. G. E.Gorman and Peter Clayton, Qualitative Research for the Information Professional: A Practical Handbook (London: Facet, 2005): 211.

14. Constace A. Mellon, "Library Anxiety: A Grounded Theory and Its Development," College \& Research Libraries 47, no. 2 (1986): 160-65.

15. Ibid., 164 .

16. Scott Carlson, "Are Reference Desks Dying Out?" Chronicle of Higher Education, Apr. 20, 2007, http:// chronicle.com/free/v53/i33/33a03701.htm (accessed Apr. 20, 2009).

17. Fister, "Fear of Reference."

18. S. R. Ranganathan, "The Fourth Law," in The Five Laws of Library Science (1931; repr., New Delhi: Ess Ess): 336-81.

19. Massey-Burzio, "From the Other Side of the Reference Desk." 